\title{
Prevention of PCDD/Fs emission from a municipal wastewater sludge incinerator through enhanced control of copper aerosol $I^{(*)}$
}

\author{
E. Peña*, S. Elcoroaristizabal*, M. Larrión*, J. A. Legarreta* and C. Gutiérrez-Cañas*
}

\begin{abstract}
Municipal wastewater sludge incineration (MWSI) leads to products of incomplete combustion, including chlorinated species such as dioxins and furans $(\mathrm{PCDD} / \mathrm{Fs})$. Other pollutants, such as heavy metals $(\mathrm{HM})$, are released too as a consequence of feed traces, which depend on the specific activities of each area. The main aim of this work is to determine whether the early separation of the potential catalysts on the PCDD/Fs formation - HM as copper or zincoffers a promising way to prevent the emission of these trace pollutants, considering that the current end-of-pipe measures don't ensure their stable emission. Experimental results cover the size distributed target metal contents along the incineration line. These results show a high concentration of copper in the most penetrating aerosol size range of the electrostatic precipitator $(0.6 \mu \mathrm{m}-1.0 \mu \mathrm{m})$, and how low emission values of both, total and metallic aerosol (mass basis), are compatible with irregular and unexplained outliers of PCDD/Fs emission.
\end{abstract}

\section{Prevención de la emisión de PCDD/Fs en un incinerador de lodos de depuradora de aguas residuales urbanas a través de un mayor control del aerosol de cobre}

\begin{abstract}
Resumen
La incineración de lodos de aguas residuales urbanas acarrea la formación de compuestos derivados de combustiones incompletas, incluyendo especies cloradas como dioxinas y furanos ( $\mathrm{PCDD} / \mathrm{Fs})$. Otros contaminantes, como metales pesados, se emiten como consecuencia de las trazas del lodo, las cuales dependen de las actividades del entorno. El objetivo principal es determinar si la separación de catalizadores potenciales en reacciones de formación de PCDD/Fs (cobre o zinc) puede abrir vías para prevenir la emisión de contaminantes traza, considerando que ninguna de las técnicas de prevención actuales aseguran emisiones estables de metales pesados o $\mathrm{PCDD} / \mathrm{Fs}$. Se determinan concentraciones de metales pesados segregados por tamaño de partícula a lo largo de la línea de incineración. Los resultados muestran concentraciones elevadas de cobre en el aerosol de máxima penetración del electrofiltro $(0,6 \mu \mathrm{m}-1,0 \mu \mathrm{m})$, y cómo concentraciones bajas de aerosol total y metálico (en masa) son compatibles con episodios de emisión no explicados de PCDD/Fs.
\end{abstract}

Palabras clave

Aerosol submicrónico; Metales pesados; PCDD/Fs; Incineración de lodos de depuradora de aguas residuales urbanas; Precipitador electrostático.

\section{INTRODUCTION}

MWSI are used to reduce the volume of the waste from urban wastewater treatments as well as for sanitizing the final material, but leads to the emission of many toxic pollutants, such as gases, HM and organic compounds. This is a crucial issue for MWSI lines which are usually close to or even within densely populated urban areas due to their functional needs. Consequently, the regulatory frame (Directive
94/67/EC; Directive 2000/76/EC) has been carefully developed including a suite of emission limit values as well as detailed BAT (Best Available Technologies). Flue gas BAT include a suite of abatement techniques, among them the separation of particulate matter (by means of Electrostatic precipitator "ESP") at medium temperature range followed by chemical scrubbing of VOCs at the low range of temperature. Studies on removal efficiency of target pollutants have been done both in

(•) Trabajo recibido el día 16 de mayo de 2012 y aceptado en su forma final el día 14 de septiembre de 2012.

* Dpt. of Chemical and Environmental Engineering. University of the Basque Country (UPV/EHU). Alameda Urquijo s/n, 48013, Bilbao, Spain. E-mail: egoitz.pena@ehu.es. Telephone number: +34946014033. Fax numbers +34946014179. 
laboratory or bench-scale and at the full-scale units $^{[1 \text { and } 2]}$. However, the unexplained variability of the emissions of toxic pollutants, mainly HM and $\mathrm{PCDD} / \mathrm{Fs}$, has been found during surveillance procedures and intensive experimental campaigns ${ }^{[3-7]}$. Moreover, the analysis of toxic pollutants is carried out off-line with time delays over one month, thus, the operation of air pollution control devices lacks in quantitative evidence about the actual performance of the line. To overcome this absence of information, many studies have attempted to establish relationships with measurable variables (such as sludge composition or process temperatures) or to search for more easily measurable surrogates. Ikonomou et al. ${ }^{[8]}$ studied the relationship with CO concentration in the flue gas, and evidences about the memory effect on the temporal scale of such correlation were found. Briois et al. ${ }^{[9]}$ studied the influence of water vapour content on the congener distribution of PCDD/Fs.

There have been many attempts to explain or predict these emissions on the basis of sludge characteristics, mainly focused on the chlorine and metallic content. These studies have been done using both real and synthetic fuels ${ }^{[10-13]}$ of a broad range of characteristics and compositions. Sludge characteristics and its elemental composition are two relevant factors because of their significant seasonal variability, as the main sources for heavy metals in wastewater are industrial activities, hospitals, households and, to a lesser degree metal wear and corrosion of the sewerage pipes. Anyway, sludge typically contains significant amounts of HM and chlorine, which enhances the metal vaporization and, thus determine the size distribution of the freshly generated aerosol. At the high temperature prevailing in the furnace, most of heavy metal species are vaporized, but later condense on the surface of the ash particles ${ }^{[14]}$. The chemical distribution of HM has been well established since McElroy et al. ${ }^{[15]}$. Many fundamental studies have done for coal-fired boilers since Whitby et al. ${ }^{[16]}$, and more recently for biomass firing or co-firing units. The interactions between aerosol metallic content and later formation of PCDD/Fs are well established by Stanmore ${ }^{[17]}$. Many authors conclude that the formation of $\mathrm{PCDD} / \mathrm{Fs}$ is related with the presence of many HM (as copper, zinc, iron or lead) and their catalytic effects on the PCDD/Fs formation reactions ${ }^{[18-20]}$ stress the role of iron chlorides and lead oxide as major catalysts. Fullana et al. [21] explains the activity of copper species as either chlorination or oxidation catalysts depending on the presence of $\mathrm{HCl}$. The temperature of the fluidized bed furnace must be at least of $880^{\circ} \mathrm{C}$ to ensure the intended combustion efficiency. At this temperature range all copper complexes are in the oxide form $(\mathrm{CuO})^{[20]}$ or combined with sulphur $-\mathrm{CuSO}_{4}-$, much stable than $\mathrm{CuO}$, but never combined with chlorides $-\mathrm{CuCl}$ or $\mathrm{CuCl}_{2}-$. Some studies say that $\mathrm{CuO}$ has a great activity on the carbon gasification and on the PCDD/Fs formation at $400^{\circ} \mathrm{C}[20]$ but this study shows that $\mathrm{PCDD} / \mathrm{Fs}$ formation occurs at around $200^{\circ} \mathrm{C}$ or less because it is found a great increase of its concentration downstream of the ESP in relation to upstream concentration. On the other hand, although the activity of the zinc compounds, mainly $\mathrm{ZnO}$ because of the combustion temperature, on the $\mathrm{PCDD} /$ Fs formation reactions is weaker than the copper complexes ${ }^{[20]}$, this study characterize it along the line as copper. Oberg et al. ${ }^{[19]}$ pointed out the surface enrichment of fly ash on copper, iron and zinc. Due to the complexity of the chemical and physical interactions, great deals of efforts have been devoted to predict the fate of heavy metals following two approaches: thermodynamic prediction and kinetic laws. Among the thermodynamically-based approaches Diaz-Somoano et al. ${ }^{[22]}$ assessed the influence of $\mathrm{HCl}$ and $\mathrm{SO}_{2}$, whereas Durlak et al. ${ }^{[23]}$ focused on the lead vaporization depending of the sodium content in the sludge and the water vapour. These predictions have been often complemented with laboratory-scale analysis, as in Chan et al. ${ }^{[24]}$ who purposely used variable amounts of chlorination agents.

Thus, an enhanced control of chemically active aerosol which leaves the ESP seems to be a promising way to prevent the formation of PCDD/Fs as well as for an efficient control in a temporal scale similar to that of changing operating conditions of the incinerator ${ }^{[25]}$. Some attempts have been made in this direction on the basis of operating parameters. Everaert et al.$^{[2]}$ found that the temperature in the ESP is the major factor in preventing dioxins emissions and state the range from 180 to $200^{\circ} \mathrm{C}$ as the optimal because of the reduction in "de novo" synthesis rate and of the maximum adsorption potential onto the fine particles.

Due to the well-known U-shaped separation efficiency of the ESP depending on the particle size, the prevalence of metals within the size range between $0.4 \mu \mathrm{m}$ and $1.0 \mu \mathrm{m}$-aerodynamic diameter " $\mathrm{d}_{\mathrm{a}}$ "- is a major issue ${ }^{[26-28]}$ as the gas cleaning device to downstream cooling and scrubbing section, in which a catalytic mechanism can prevail leading to high rates of $\mathrm{PCDD} / \mathrm{Fs}$ formation. This abatement strategy must be based on maximizing the fractional efficiency for the size bins in which the maximum amount of active metallic species occurs. 


\section{METHODS AND EXPERIMENTAL SECTION}

The wastewater treatment plant is located within a densely populated urban area of about one million inhabitants (Bilbao, Spain). The 1-year experimental campaign was designed to assess the seasonal variability. The capacity of this plant is between 120 and $210 \mathrm{t}$ sludge/day [wet basis]. The natural gas average consumption is up to $2300 \mathrm{~m}^{3} /$ day. During this campaign sludge rate was around $168 \mathrm{t} /$ day [wet basis] resulting around $18.5 \mathrm{t}$ bottom ash/day [dry basis]. Figure 1(A) depicts the flow diagram of the incineration line as well as sampling positions for aerosol and for bulk solids.

Figure 1(B) sketches the sampling trains for aerosol measurements. The raw sludge is fed to a fluid bed furnace operating at a nominal value of $925^{\circ} \mathrm{C}$. If the temperature falls below $850^{\circ} \mathrm{C}$ the sludge feed is discontinued. No major incidents occurred along the experimental campaign. The heat recovery system consists of a boiler and an economizer. The gas temperature at the outlet of them is slightly over $200^{\circ} \mathrm{C}$ and the dust load is higher than $60 \mathrm{~g} / \mathrm{Nm}^{3}$. This stream was analyzed along the campaign, sampling position is denoted as $\# 2$ in the figure $1(A)$. This position lies between the second and third tube bundles and was chosen according to the representativeness requirements, internal pipe accessibility and workspace needs. Samples of ashes from the heat recovery unit were collected for further analysis (sampling points \#5 and \#6 in figure $1(A)$ ). The ESP operates at a voltage between $85 \mathrm{kV}$ and $105 \mathrm{kV}$. Samples from hoppers were taken at position \#7; sampling and analysis position for the exit gas was done at position \#3 (at a straight section). The overall efficiency is claimed to be $>99.9 \%$ in mass basis. Neither data about fractional efficiency nor about the aerosol size distribution was available prior to these experiments. The end-of-pipe chemical scrubbing absorbs gaseous pollutants such as acid gases and VOCs. All aerosol sampling sections are according with UNE EN ISO 13284-1.

Each experiment gives aerosol data in two temporal scales: real and time-integrated over the sampling period. Real-time aerosol analysers give the size distribution in a temporal scale comparable to that of process dynamics. Time-integrated aerosol instruments are used to collect samples for further chemical analysis. Thus, in the later case the process stability has been set as a necessary condition. A similar methodology has been undertaken in other studies of aerosol dynamics from full-scale thermal processes [26, 27 and 29, 30].

Real-time size distribution analysis in the range from $30 \mathrm{~nm}$ to $10 \mu \mathrm{m}$ was performed by means of an

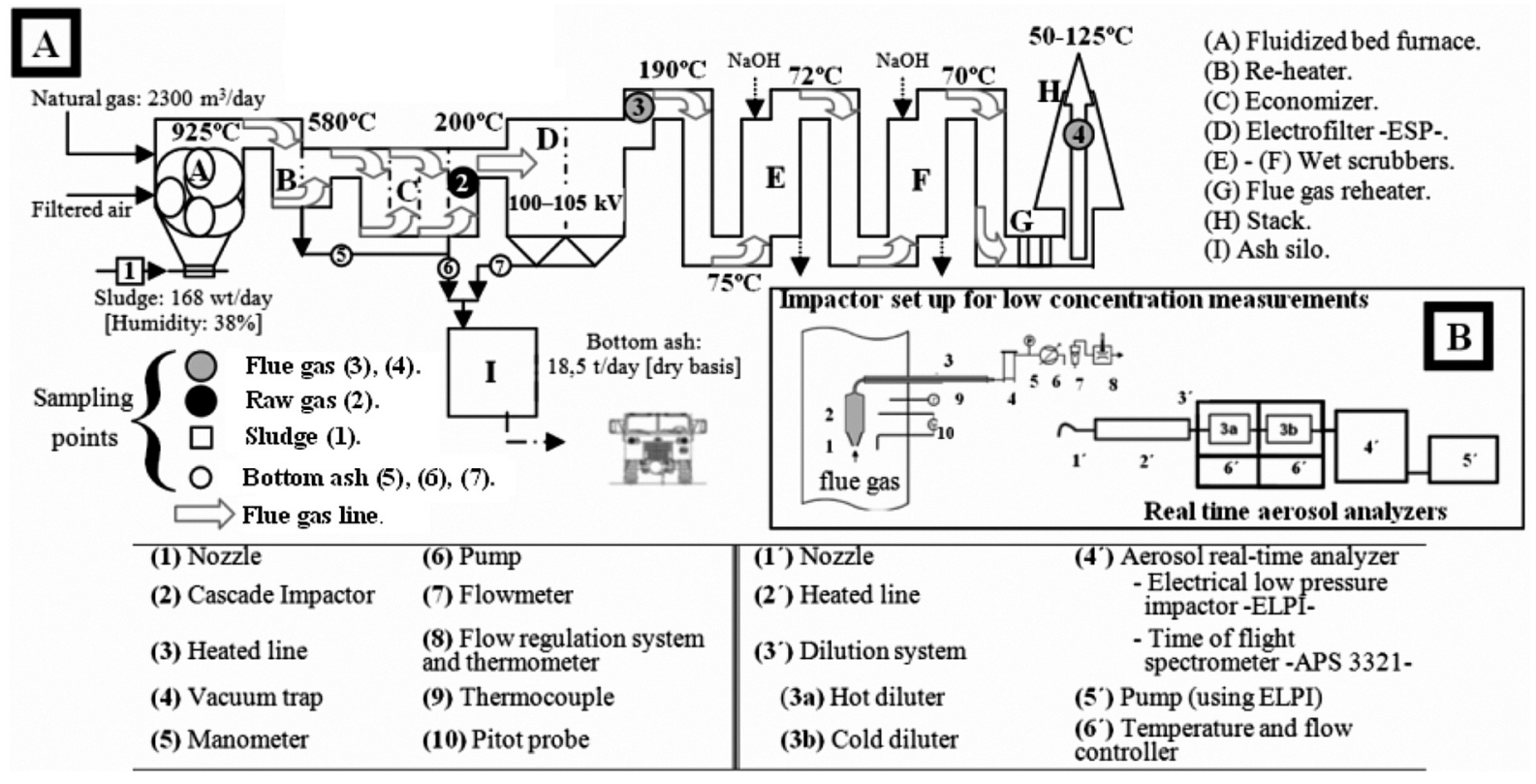

Figure 1 (A). Flow diagram: Sludge, raw gas and fly and bottom ash sampling points with some of the most relevant operating variables. (B) Real and time integrated sampling trains.

Figura 1 (A). Diagrama de flujo: Puntos de muestreo del lodo, gas bruto y cenizas volantes y de fondo con algunas de las variables de operación más relevantes. (B) Esquema de los trenes de muestreo de tiempo real e integrado en el tiempo de medida. 
Electrical Low Pressure Impactor (ELPI, Dekati), whose primary signals are the charges which arrive to the impaction plates along the thirteen stages of the cascade impactor as described in Marjamäki

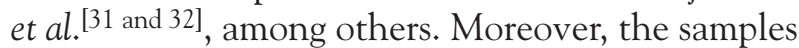
collected on these impaction substrates over the sampling time allow to further analysis and to establish relationships among size, morphology and composition of particles. In the range of $0.5 \mu \mathrm{m}$ and $20 \mu \mathrm{m}$, the size distributions of aerodynamic diameters were obtained using a time-of-flight spectrometer without collecting the measured aerosol ${ }^{[33]}$ (APS3321, TSI). Both real-time analysers need a sampling train with a dilution system, which uses dry and filtered compressed air through two ejectors in series to condition the samples and to avoid condensation $^{[34}$ and 35] (Fig. 1(B)).

Cascade impactors are used mainly as sample preseparators for further analysis as morphological (SEM/EDS and ICP-MSS). Furthermore, total mass concentration of particle matter (PM) was determined in accordance with ISO/FDIS 23210 during this characterization campaign. Kalman KS-220 (according to VDI 2066) in-stack cascade impactor takes advantage of a twin impact stage set on the same cut diameter as significant to improve its performance under high loadings of particulate matter, thus matching the conditions for sampling upstream of the ESP. The operation and data interpretation has been made on the well-established methodology for cascade impactor data ${ }^{[15}$ and 36-38]. The sampling trains are enclosed in the figure 1(B) and a detailed description of each one can be found in Maguhn et al. ${ }^{[39]}$.

A previous campaign was carried out along two months with a double objective and with at least eleven experiments. The first objective was to prepare the sampling ports, the ancillary services and lines, communications and logistic as well as to establish on the basis of the measured range of flow conditions (velocity fields across the measurement planes, temperatures and aerosol loads) and the appropriate QA/QC procedures. The second one consists of verifying the range of trace pollutants emission as obtained from historical records. Emission measurements of total PM $\left(1.0-2.0 \mathrm{mg} / \mathrm{Nm}^{3}\right)$ and $\mathrm{HM}\left(<5 \mu \mathrm{g} / \mathrm{Nm}^{3}\right.$, when total mass concentration $<1 \mathrm{mg} / \mathrm{Nm}^{3}$ ) fulfill the current legislation limits, in agreement with the routine compliance surveillance analysis carried out by other certificated entities. Confirming historical records, unexplained higher values of PCDD/Fs emissions occur without apparent correlation neither to chlorine content of the sludge nor to combustion and gas cleaning operation. The span of these concentrations is over $350 \%$, ranging from values well below the emission limit but higher than the laboratory detection limit.

\section{RESULTS AND DISCUSSION}

Results for an intensive campaign are presented (more than thirty valid experiments over six months of regular operation) for sampling points $\# 1, \# 2$ and $\# 3$ (Fig. 1(A)). Sampling point \#4 was discarded on the basis of the results of the preliminary campaign because of its relatively low significance in terms of prevention; the chemical scrubbing is not effective to distort neither the total mass nor the metallic content of the aerosol. This was further verified by simultaneous measurements at the ESP outlet and at the stack.

Seasonal variability of the sludge was taken into account to focus the characterization campaign according to the real needs of the plant. The daily average of the sludge feed was $168 \mathrm{t} /$ day during the characterization campaign compared with the historical average which was $170 \mathrm{t} /$ day. The composition of copper, zinc and lead were according to the historical values. Campaign and historical daily averages were $225 \mathrm{ppm}$ - $213 \mathrm{ppm}$ for copper, $626 \mathrm{ppm}$ $-783 \mathrm{ppm}$ for zinc and $112 \mathrm{ppm}-130 \mathrm{ppm}$ for lead respectively. On the other hand, active metals concentration values during the characterization campaign against the historical measures in the ESP bottom ash ( $\# 7$, Fig. 1) were $618 \mathrm{ppm}-631 \mathrm{ppm}$ (copper), $1785 \mathrm{ppm}-3143 \mathrm{ppm}$ (zinc) and $315 \mathrm{ppm}$ $-343 \mathrm{ppm}$ (lead).

Total mass concentration of PM upstream of the ESP was $\geq 60 \mathrm{~g} / \mathrm{Nm}^{3}\left(58-101 \mathrm{~g} / \mathrm{Nm}^{3}\right.$; median value around $70 \mathrm{~g} / \mathrm{Nm}^{3}$ ) with a relative humidity $(\mathrm{RH})$ spanning from $35 \%$ to $45 \%$. Its value is fairly stable over recording periods longer that those of samplings. Figure 2 shows the gravimetric size distributions obtained by cascade impactors located at sampling points $\# 2$ and $\# 3$ (Fig. 1(A)).

A cyclone of $\mathrm{d}_{50}=10 \mu \mathrm{m}$ was used to prevent early closing and impactor overloading. The size distribution is shifted to the coarse fraction $(>10 \mu \mathrm{m})$ upstream of the ESP $(94.7 \%$ of the total mass collected by the impactor). This remains practically invariable along the characterization campaign.

Because of the risk of the back corona effect and thus, the collapse of the ESP, the applied voltage was automatically regulated within a broad range of values, from $85 \mathrm{kV}$ to $105 \mathrm{kV}$. This cause a rather high variability of both total mass concentration $\left(1.0 \mathrm{mg} / \mathrm{Nm}^{3}\right.$ to $6.8 \mathrm{mg} / \mathrm{Nm}^{3}$ with $35 \%$ - $45 \%$ of $\mathrm{RH})$ and size distribution downstream of the ESP. The predominant aerosol size fraction is the PM2.5, 

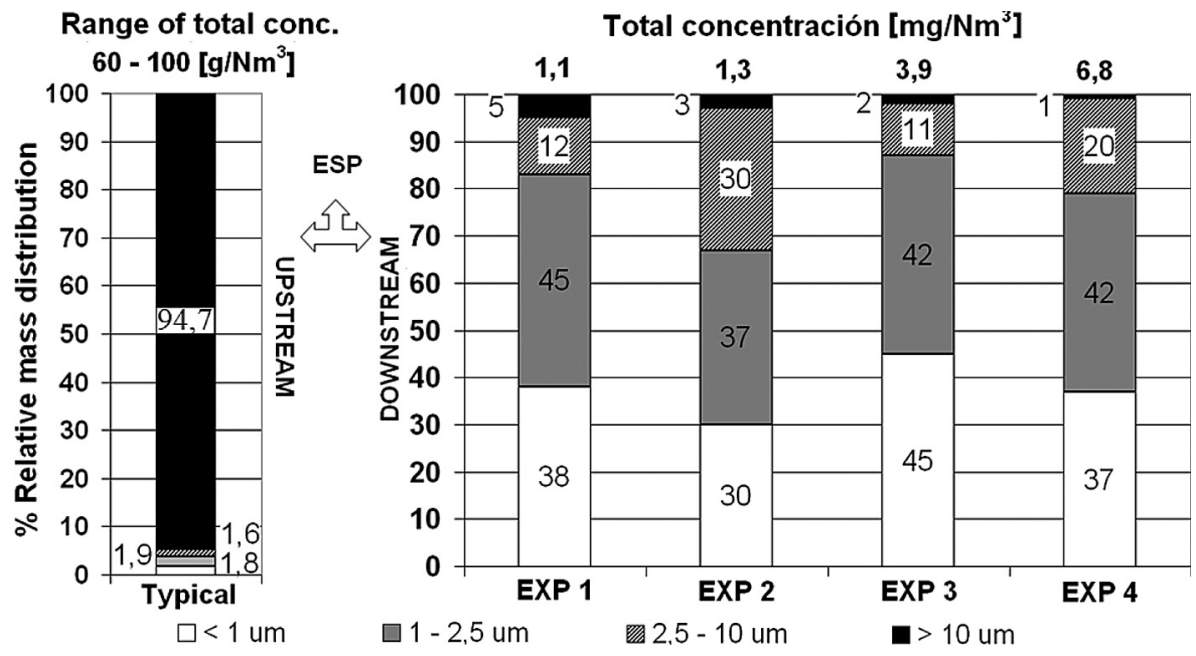

Figure 2. Time integrated size distribution and total mass concentration measurements using cascade impactors [Kalman KS-220]. (Left) Usual values upstream of the ESP. (Right) Typical size distributions at overall range of total mass concentrations downstream of the ESP.

Figura 2. Medidas de distribución de tamaño y de concentración total en masa integradas en el tiempo obtenidas mediante impactadores en cascada [Kalman KS-220]. (Izq.) Valores típicos antes del electrofiltro. (Drcha.) Distribuciones de tamaño habituales en todo el rango de concentración total en masa tras el electrofiltro.

accounting for up to $80 \%$ of the total mass concentration; the fraction comprised between $1.0 \mu \mathrm{m}$ and $2.5 \mu \mathrm{m}$ is the responsible of the $37 \%$ $45 \%$ of the total mass concentration and the submicron aerosol of the $30 \%-45 \%$ of it. Figure 3 (up) shows a typical averaged size distribution for the micron and submicron range over the measurement time (around 1 to $1.5 \mathrm{~h}$ ).

The main mode of the mass size distribution is shifted from $4-5 \mu \mathrm{m}\left(\mathrm{d}_{\mathrm{ae}}\right)$ upstream of the ESP to the range of $0.6-2.0 \mu \mathrm{m}\left(\mathrm{d}_{\mathrm{ae}}\right)$ downstream of it [72- $78 \%$ of the total mass]. These results, coherent to those obtained from time-integrated measurements at an effective density slightly over 1 , stress the relevance of the submicron range of aerosol downstream of the ESP.

Figure 3 (down) shows a typical curve for the fractional efficiency as obtained from simultaneous real-time measurements of aerodynamic diameter $\left(\mathrm{d}_{\mathrm{ae}}\right)$ at the inlet and outlet of the ESP. This curve spans over the range of measurement, which is a result of the merger of the aerodynamic size distributions obtained by means of the ELPI and APS. The difference at the minimum of the curve of the fractional efficiency is less than $0.14 \%$ and it captures the characteristics of both instruments. The size range of the penetration window of this particular ESP was found between $0.6 \mu \mathrm{m}$ and $1.0 \mu \mathrm{m}$. Rebounds
$(>2.5 \mu \mathrm{m})$ and diffusion losses $(<0.4 \mu \mathrm{m})$ were frequently observed in the corresponding stages of the ELPI. Nevertheless, these operational problems do not affect the range for this study, which lies between $0.5 \mu \mathrm{m}$ and $2.5 \mu \mathrm{m}$.

Elemental analysis of bulk materials, that are the sludge and ashes from sampling points $\# 1, \# 5, \# 6$ and $\# 7$ as denoted in figure 1(A), was done off-site by means of an ICP/MS. The iron concentration in the sludge is relatively constant over the entire campaign at high values around $13000 \mathrm{ppm}$. The lead concentration behaves in a similar manner at values below $130 \mathrm{ppm}$. In the case of both copper and zinc, the range of concentrations in the sludge is extended significatively: $100-400 \mathrm{ppm}$ for copper and $500-1000 \mathrm{ppm}$ for zinc. These data, as well as the operational records, support the hypothesis that high concentration episodes of PCDD/Fs should be related with variable amounts of chemically active copper and zinc species. As previously discussed, kinetic factors indicate that variable amounts of copper should have a relevant influence on the production of PCDD/Fs.

Concentrations of relevant metals (lead, zinc, and copper) in the fly ash were determined by an ICP/MS in both total and size-seggregated samples. Lead concentration is always under the detection limit of the ICP/MS. The median value for zinc is $3529 \mathrm{ppm}$, 
PREVENTION OF PCDD/FS EMISSION FROM A MUNICIPAL WASTEWATER SLUDGE INCINERATOR THROUGH ENHANCED CONTROL OF COPPER AEROSOL PREVENCIÓN DE LA EMISIÓN DE PCDD/FS EN UN INCINERADOR DE LODOS DE DEPURADORA DE AGUAS RESIDUALES URBANAS A TRAVÉS DE UN MAYOR CONTROL DEL AEROSOL DE COBRE
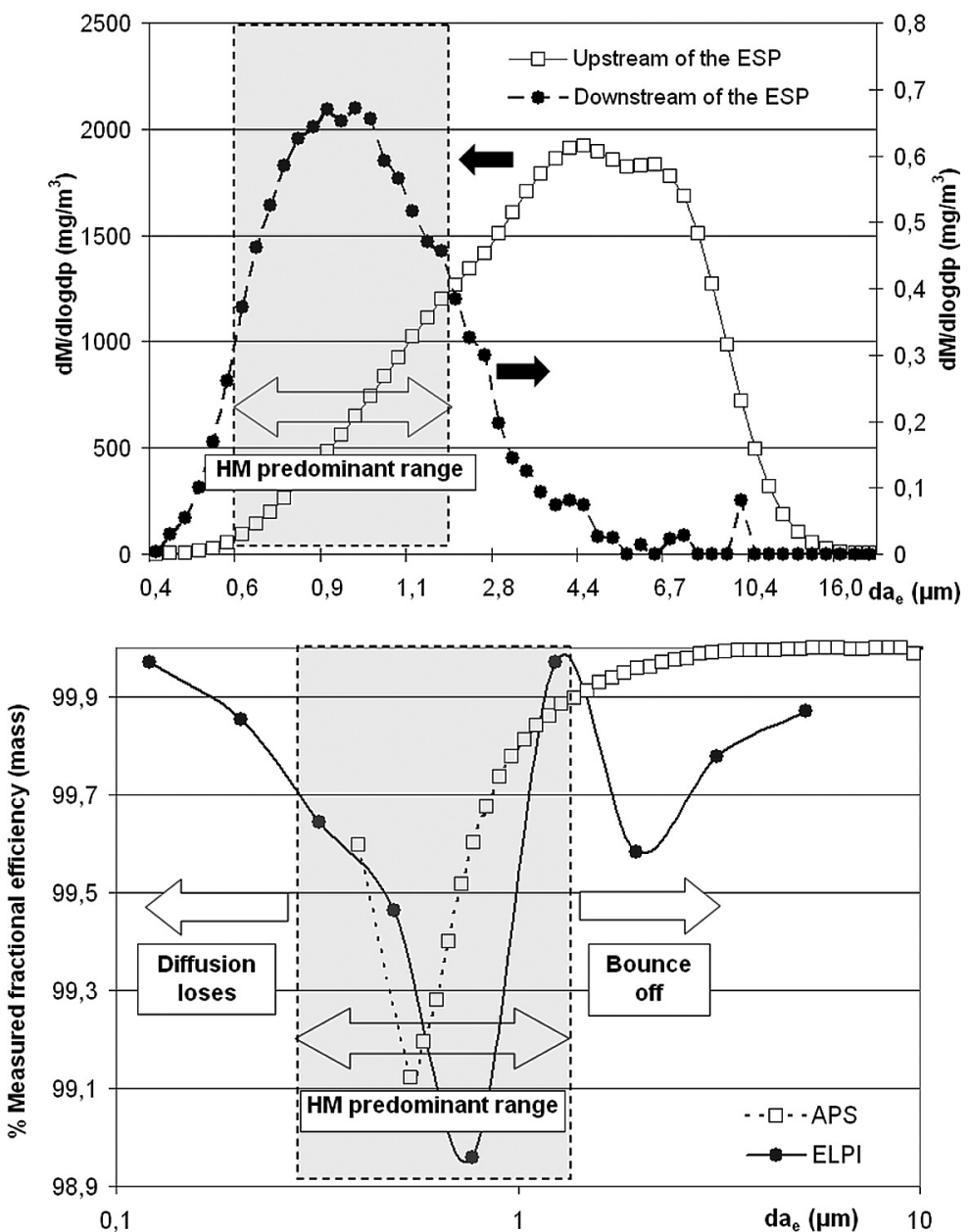

Figure 3. (Up) Real time measurements using ELPI (Dekati) and APS 3321 (TSI). (Down) ESP fractional efficiency through real time measurements.

\section{Figura 3. (Arriba) Medidas en tiempo real obtenidas con el ELPI (Dekati) y con el APS 3321 (TSI). (Abajo) Eficacia frac- cional del electrofiltro calculada con las medidas en tiempo real.}

ranging from $2394 \mathrm{ppm}$ to $30000 \mathrm{ppm}$ in the particle size range of $0.95 \mu \mathrm{m}-2.4 \mu \mathrm{m}$. The median value for copper is $12857 \mathrm{ppm}$, ranging from $1034 \mathrm{ppm}$ to $13333 \mathrm{ppm}$ in the particle size range below $1.0 \mu \mathrm{m}$ (Fig. 4).

Size-seggregated elemental analysis for samples collected onto the impactor stages illustrates clearly the differences between copper and zinc distribution over size. In terms of individual variability, copper concentration reaches outliers up to 4 -fold its average value in the PM10 fraction after the ESP, whereas maximum zinc concentration is about 2 times its mean concentration.

Size-seggregated concentration of copper upstream of the ESP shows an evenly split between the coarse and the fine fractions $(150 \mathrm{ppm}$ in the range of $d_{p} \leq 8 \mu \mathrm{m}$ and 180 ppm for $\left.d_{p} \geq 8 \mu \mathrm{m}\right)$. However, size-seggregated results of copper downstream of the ESP show that although it is accumulated in the submicron aerosol, where the penetration window of the ESP $(0.6 \mu \mathrm{m}-1.0 \mu \mathrm{m})$ occurs, it shows a high variability in a daily basis in a yearly scale (Fig. 3 (down) and Fig. 4). In addition to this, these variable copper splits were observed under similar furnace operating conditions, sludge compositions $(172-219 \mathrm{ppm})$ or even with similar values of total copper concentrations in the PM10 fraction downstream of the ESP $\left(1.8 \mu \mathrm{g} / \mathrm{Nm}^{3}-\right.$ $5.2 \mu \mathrm{g} / \mathrm{Nm}^{3}$ ) and thus, this variability is uncorrelated with them. Therefore, the copper content in the fly ash should be measured by size-seggregated particle size to avoid the dilution effect which happens if 
the total aerosol concentration, or even PM10 and PM2.5 fractions, is analysed to determinate its filtration efficiency and its influence in the formation of $\mathrm{PCDD} / \mathrm{Fs}$ as a catalyser.

The zinc content of the sludge $(563-626 \mathrm{ppm})$ is higher than the copper content and it shows a moderate variability. The trend of the zinc is to condense in the ESP high efficiency aerosol size range $(>1 \mu \mathrm{m})$ (Fig. 3 (down) and Fig. 4) and thus, its emission is controlled. On the other hand, although the total concentration of zinc in the fly ash (PM10) is greater $\left(8.6-19 \mu \mathrm{g} / \mathrm{Nm}^{3}\right)$ than the concentration of copper $\left(1.8 \mu \mathrm{g} / \mathrm{Nm}^{3}-5.2 \mu \mathrm{g} / \mathrm{Nm}^{3}\right)$, its impact on the PCDD/Fs formation will be lower because of the dilution effect explained before, which depends on the proper choice of the particle size range analysed, and other kinetic factors; see the size-seggregated concentration of them in the figure 4.

Focusing this study in the PCDD/Fs emissions, the experimental results show a strong relation between emission episodes of them with high concentrations of copper in the PM1 fraction of the fly ash under typical sludge feed and nominal operation of the incineration line.

\section{CONCLUSIONS}

- This study establishes the necessity of measuring the HM content of particles seggregated by particle size to avoid the dilution effect which occurs if greater fractions, such as PM10 or PM2.5, are analyzed. Results show how copper is accumulated on particles of the penetration size range of the ESP $(0.6 \mu \mathrm{m}-1.0 \mu \mathrm{m})$, showing a high concentration variability over time in a yearly scale. Moreover, this temporal evolution is uncorrelated with both the controlled process variables and the sludge composition. Other heavy metals with potential catalytic activity, such as zinc, condense on particles greater than $1.0 \mu \mathrm{m}$ and its content is well controlled by the ESP.

- The copper content of particles penetrating the ESP has been identified as the most promising variable to control the dioxin-furans emissions. The PCDD/Fs emission episodes detected along the characterization campaign are correlated with high concentrations of copper in the PM1 fraction.

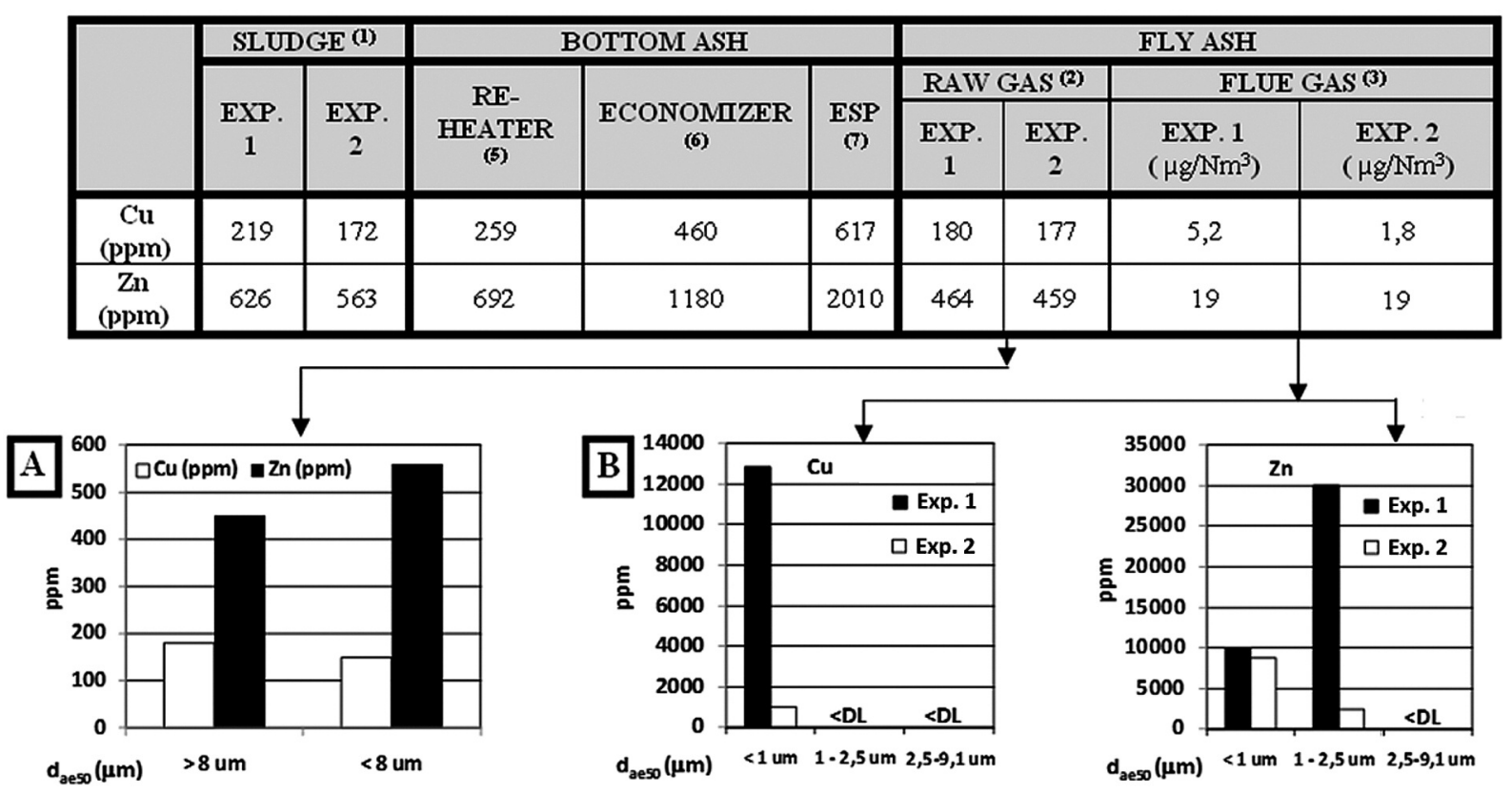

Figure 4. Copper and zinc pathway (size seggregated-total concentration). (A) The split is roughly the same upstream of the ESP for the coarse fraction -raw gas-. (B) Fly ash copper and zinc concentrations variability under similar operating conditions; zinc is present in the micron range whereas copper is concentrated in the submicron range of the penetrating aerosol.

Figura 4. Comportamiento preferencial del cobre y del zinc (concentración total segregada por tamaño). (A) El reparto entre fracciones es similar antes del electrofiltro -gas bruto-. (B) Variabilidad de las concentraciones de cobre y zinc en las cenizas volantes bajo condiciones de operación similares; el zinc se acumula por encima de una micra mientras que el cobre lo hace en el rango submicrónico del aerosol de penetración del electrofiltro. 


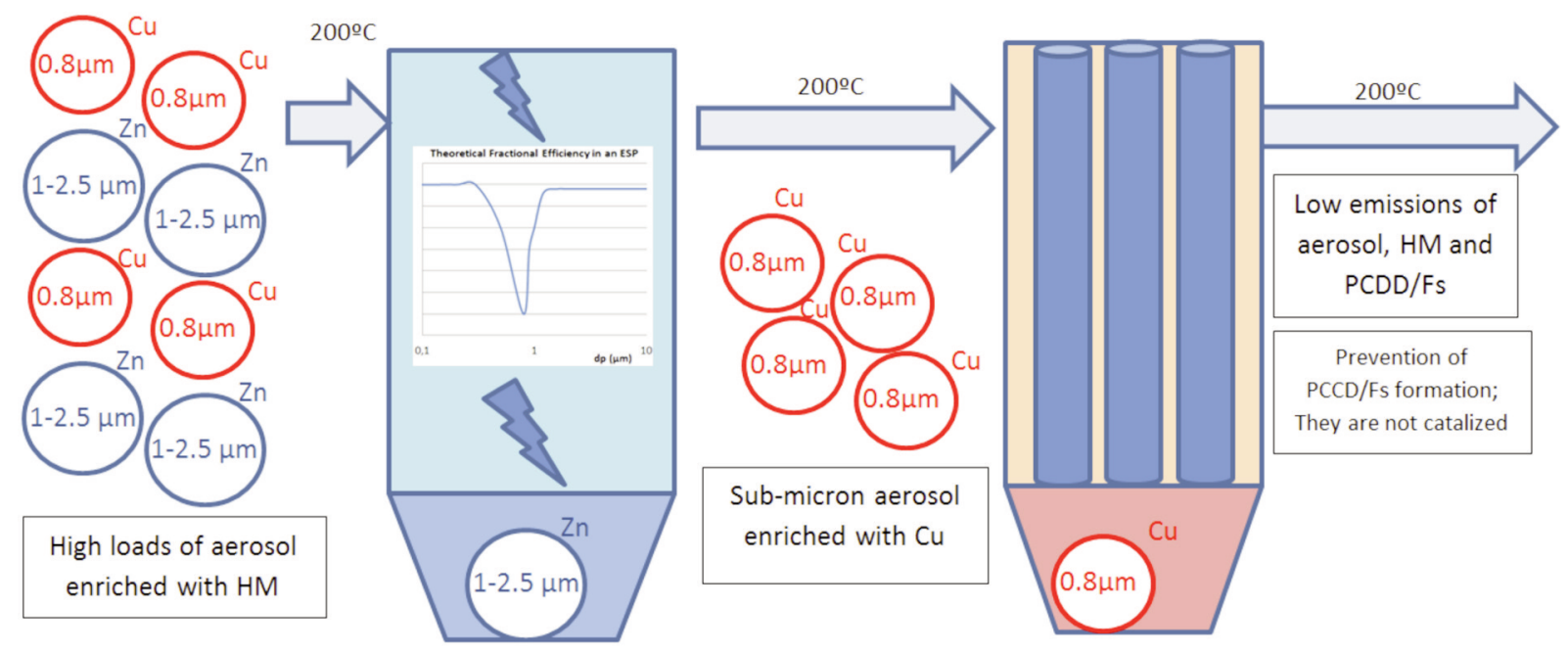

Figura 5. Synopsis Toc. The size-seggregated characterization of the chemically active metals and the implementation of a combined filtration theory to achieve high efficiencies in the ESP most penetrating aerosol range, in which copper is concentrated, could be one of the best ways to reduce both HM emissions and the PCCD/Fs formation.

Figura 5. Esquema conceptual. La caracterización segregada por tamaño de los metales químicamente activos y la implementación de una teoría de filtración combinada para aumentar la eficacia de retención en el rango de máxima penetración del electrofiltro, en el cual se acumula el cobre, puede ser una de las mejores alternativas para reducir tanto la emisión de metales pesados como la formación de PCDD/Fs.

- After this characterization campaign, a bag filter was set directly downstream of the ESP to increase at least $0.5 \%$ (mass basis) the filtration efficiency in the size penetration range of the ESP $(0.6 \mu \mathrm{m}$ $-1.0 \mu \mathrm{m})$. After this improvement, emission outliers of $\mathrm{PCDD} /$ Fs were not observed in the six next months that follow ( 1 analysis per month). These results open a new way to link the concentration of PCDD/Fs with the presence of copper in the submicron aerosol. A prospect of real-time monitoring is envisaged using a combination of an aerosol classifier, such as DMA (differential mobility analyzer), and a specific copper detector (on-going work).

\section{Acknowledgements}

This work was funded by El Consorcio de Aguas del Gran Bilbao (Spain) and supported by Chemical and Environmental Engineering Department of the University of the Basque Country (Spain) and by Aerosol Industrial Research group. A special agrement for J. Aguirre, M. Lueje, O. Redondo and the staff who have promoted, contributed and implemented the results of this Project.

\section{REFERENCES}

[1] S. C. Kim, S. H. Jeon, I. R. Jung, K. H. Kim, M. H. Kwon, J. H. Kim, J. H. Yi, S. J. Kim, J. C. You and D. H. Jung, Chemosphere 43 (2001) 773-776.

[2] K. Everaert, J. Baeyens and J. Degréve, Environ. Sci. Technol. 37 (2003) 1219-1224.

[3] J. Y. Ryu, J. A. Mulholland, J. E. Dunn, F. Lino and B. K. Gullett, Environ. Sci. Technol. 38 (2004) 5112-5119.

[4] K. Neuer-Etscheidt, H. O. Nordsieck, Y. Liu, A. Kettrup and R. Zimmermann, Environ. Sci.Technol. 40 (2006) 342-349.

[5] H. L. Wang, Z. P. Hao, Y. H. Zhuang, W. Wang and X. Y. Liu, Energ. Fuel 22 (2008) 1636-1640.

[6] W. H. Rulkens, Energ. Fuel 22 (2008) 9-15.

[7] E. Peña, S. Astarloa, E. García, S. Elcoroaristizabal, J. A. Legarreta and C. Gutiérrez-Cañas, European Aerosol Conference, vol. 1, Karlsruhe, Germany, 2009, G. Kasper y G. Metzig (Eds.), GAeF, Karlsruhe, Germany, 2009, ref. T081A04.

[8] M. G. Ikonomou, P. Sather, J. E. Oh, W. Y. Choi and Y. S. Chang, Chemosphere 49 (2002) 205-216.

[9] C. Briois, S. Ryan, D. Tabor, A. Touati and B. K. Gullett, Environ. Sci. Technol. 41 (2007) 850-856. 
[10] T. Öberg and T. Ohrstrom, Environ. Sci. Technol. 37 (2003) 3995-4000.

[11] S. Kuzuhara, H. Sato, E. Kasai and T. Nakamura, Environ. Sci. Technol. 37 (2003) 2431-2435.

[12] S. P. Ryan and E. R. Altwicker, Environ. Sci. Technol. 38 (2004) 1708-1717.

[13] Q. Sun, M. Altarawneh, B. Z. Dlugogorski, E. M. Kennedy and J. C. Mackie, Environ. Sci. Technol. 41 (2007) 5708-5715.

[14] T. Lind, T. Valmari, E. I. Kauppinen, G. Sfiris, K. Nilsson and W. Maenhaut, Environ. Sci. Technol. 33 (1999) 496-502.

[15] M. W. McElroy, R. C. Carr, D. S. Ensor and G. R. Markowski, Science 215 (4528), (1982) 13-19.

[16] K. T. Whitby, B. K. Cantrell and D. B. Kittelson, Atmos. Environ. 12 (1978) 313-321.

[17] B. R. Stanmore, Combust. Flame 136 (2004) 398-427.

[18] M. B. Chang, K. H. Chi and G. P. ChangChien, Chemosphere 55 (2004) 1457-1467.

[19] T. Öberg, B. Bergbäck and E. Öberg, Environ. Sci. Technol. 41 (2007) 3741-3746.

[20] T. Fujimori, M. Takaoka and N. Takeda, Environ. Sci. Technol. 43, (2009) 8053 - 8059.

[21] A. Fullana, J. A. Conesa, R. Font and S. Sidhu, Environ. Sci. Technol. 38 (2004) 2953-2958.

[22] M. Diaz-Somoano, S. Unterberger and K. R. G. Hein, Fuel 85 (2006) 1087-1093.

[23] S. K. Durlak, P. Biswas and J. Shi, J. Hazard. Mater. 56 (1997) 1- 20.

[24] C. Chan, C.Q. Jia, J.W. Graydon and D.W. Kirk, J. Hazard. Mater. 50 (1996) 1-13.

[25] E. Peña, J. J. Aguirre, S. Astarloa, S. Elcoroaristizabal, J. A. Legarreta and C. Gutierrez-Cañas, Chemical Engineering Transaction 22 (2010) 125-130.

[26] T. Lind, J. Hokkinen, J. K. Jokiniemi, S. Saarikoski and R. Hillamo, Environ. Sci. Technol. 37 (2003) 2842-2846.
[27] T. Ferge, J. Maguhn, H. Felber and R. Zimmermann, Environ. Sci. Technol. 38 (2004) 1545-1553.

[28] E. Peña, Tesis Doctoral, Escuela Técnica Superior de Ingeniería de Bilbao, Universidad del País Vasco, 2010.

[29] J. Latva-Somppi, M. Moisio, I. E. Kauppinen, T. Valmari, P. Ahonen, U. Tapper and J. Keskinen, J. Aerosol Sci. 29 (4), (1998) 461-480.

[30] E. Peña, E. García and C. Gutiérrez-Cañas, The American Association for Aerosol Research, vol. 1, Minnesota, USA, 2009, D. Bright y M. Baldwin (Eds.), AAAR, Minnesota, USA, 2009, ref. 10B.3.

[31] M. Marjamäki, J. Keskinen, D. R. Chen and D. Y. H. Pui, J. Aerosol Sci. 31 (2000) 249-261.

[32] M. Marjamäki, M. Lemmetty and J. Keskinen, Aerosol Sci. Tech. 39 (2005) 575-582.

[33] R. L. Holm, R. Caldow, P. P. Hairston, F. R. Quant and G. J. Sem, J. Aerosol Sci. 28 (1997) S11-S12.

[34] J. Lyyranen, J. Jokiniemi and E. I. Kauppinen, Aerosol Sci. Tech. 38 (2004) 12-23.

[35] H. Burtscher, S. Künzel and C. Hüglin, Aerosol Sci. Tech. 36 (2005) 896-932.

[36] J.M. Pilat, D.S. Ensor and J.C. Bosch, American Industrial Hygiene Association Journal 1 (1978) 508-511.

[37] G. R. Markowski, D. S. Ensor, R. G. Hooper and R. C. Carr, Environ. Sci. Technol. 14 (1980) 1400-1402.

[38] D.S. Ensor, P.A. Lawless, A.S. Damle and L.E. Sparks, EPA 3rd Symposium on the Transfer and Utilization of Particulate Control Technology, vol. 1, Florida, USA, 1981, National Service Center for Environmental Publications (NSCEP), USA, 1981.

[39] J. Maguhn, E. Karg, A. Kettrup and R. Zimmermann, Environ. Sci. Technol. 37 (2003) 4761-4770. 